\title{
Combining Satellite Data with Ancillary Data to Produce a Refined Land-Use/Land-Cover Map
}

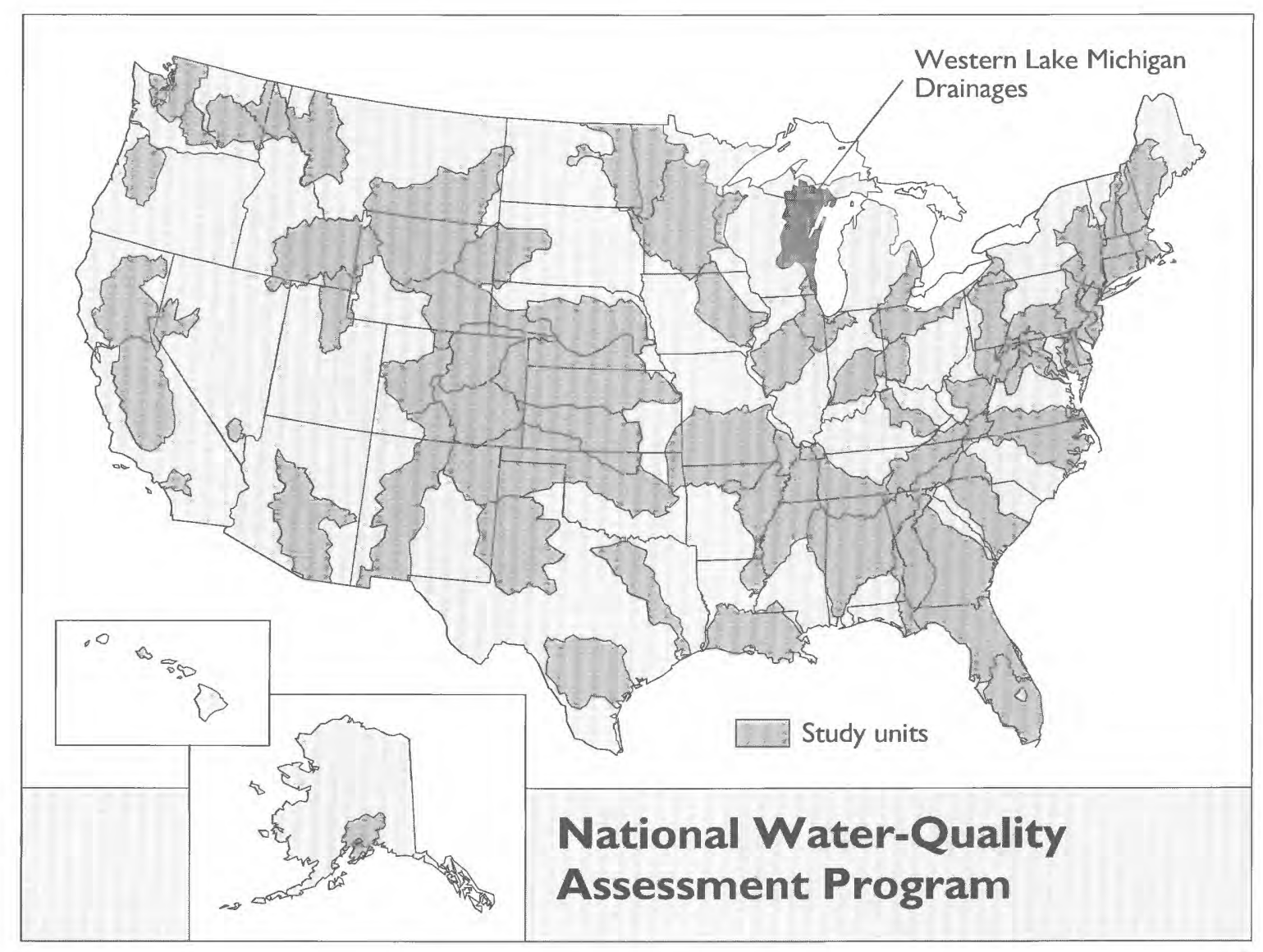




\section{COMBINING SATELLITE DATA WITH ANCILLARY DATA TO PRODUCE A REFINED LAND-USE/LAND-COVER MAP}

By Jana S. Stewart

U.S. GEOLOGICAL SURVEY

Water-Resources Investigations Report 97-4203

NATIONAL WATER-QUALITY ASSESSMENT PROGRAM WESTERN LAKE MICHIGAN DRAINAGES

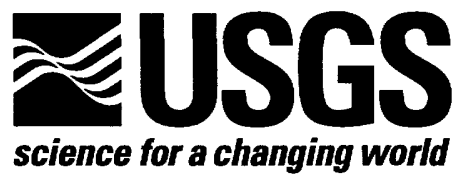




\title{
U.S. DEPARTMENT OF THE INTERIOR BRUCE BABBITT, Secretary
}

\author{
U.S. GEOLOGICAL SURVEY \\ Thomas J. Casdevall, Acting Director
}

For additional information write to:

Copies of this report can be purchased from:

District Chief

U.S. Geological Survey

8505 Research Way

Middleton, WI 53562
U.S. Geological Survey

Branch of Information Services

Box 25286

Denver, CO 80225-0286 


\section{FOREWORD}

The mission of the U.S. Geological Survey (USGS) is to assess the quantity and quality of the earth resources of the Nation and to provide information that will assist resource managers and policymakers at Federal, State, and local levels in making sound decisions. Assessment of water-quality conditions and trends is an important part of this overall mission.

One of the greatest challenges faced by waterresources scientists is acquiring reliable information that will guide the use and protection of the Nation's water resources. That challenge is being addressed by Federal, State, interstate, and local water-resource agencies and by many academic institutions. These organizations are collecting water-quality data for a host of purposes that include compliance with permits and water-supply standards; development of remediation plans for specific contamination problems; operational decisions on industrial, wastewater, or watersupply facilities; and research on factors that affect water quality. An additional need for water-quality information is to provide a basis on which regionaland national-level policy decisions can be based. Wise decisions must be based on sound information. As a society we need to know whether certain types of water-quality problems are isolated or ubiquitous, whether there are significant differences in conditions among regions, whether the conditions are changing over time, and why these conditions change from place to place and over time. The information can be used to help determine the efficacy of existing waterquality policies and to help analysts determine the need for and likely consequences of new policies.

To address these needs, the U.S. Congress appropriated funds in 1986 for the USGS to begin a pilot program in seven project areas to develop and refine the National Water-Quality Assessment (NAWQA) Program. In 1991, the USGS began full implementation of the program. The NAWQA Program builds upon an existing base of water-quality studies of the USGS, as well as those of other Federal, State, and local agencies. The objectives of the NAWQA Program are to

- Describe current water-quality conditions for a large part of the Nation's freshwater streams, rivers, and aquifers.
- Describe how water quality is changing over time.

- Improve understanding of the primary natural and human factors that affect water-quality conditions.

This information will help support the development and evaluation of management, regulatory, and monitoring decisions by other Federal, State, and local agencies to protect, use, and enhance water resources.

The goals of the NAWQA Program are being achieved through ongoing and proposed investigations of 59 of the Nation's most important river basins and aquifer systems, which are referred to as Study Units. These Study Units are distributed throughout the Nation and cover a diversity of hydrogeologic settings. More than two-thirds of the Nation's freshwater use occurs within the 59 Study Units, and more than twothirds of the people served by public water-supply systems live within their boundaries.

National synthesis of data analysis, based on aggregation of comparable information obtained from the Study Units, is a major component of the program. This effort focuses on selected water-quality topics using nationally consistent information. Comparative studies will explain differences and similarities in observed water-quality conditions among study areas and will identify changes and trends and their causes. The first topics addressed by the national synthesis are pesticides, nutrients, volatile organic compounds, and aquatic biology. Discussions on these and other waterquality topics will be published in periodic summaries of the quality of the Nation's ground water and surface water as the information becomes available.

This report is an element of the comprehensive body of information developed as part of the NAWQA Program. The program depends heavily on the advice, cooperation, and information from many Federal, State, interstate, Tribal, and local agencies and the public. The assistance and suggestions of all are greatly appreciated.

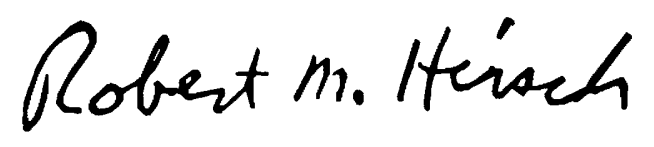

Robert M. Hirsch Chief Hydrologist 


\section{CONTENTS}

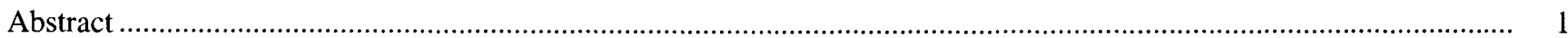

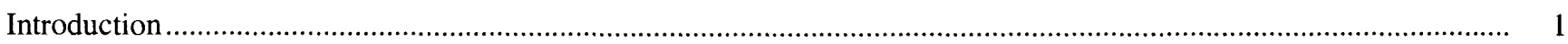

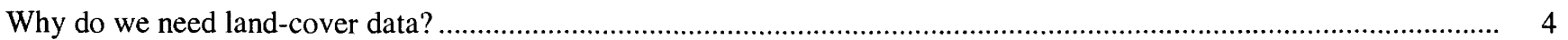

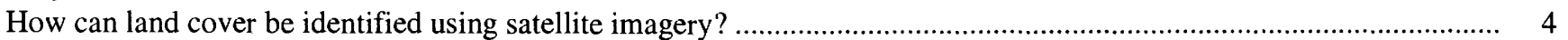

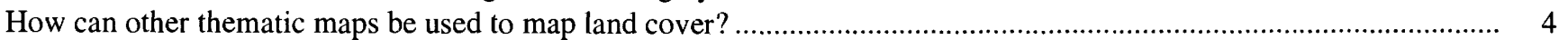

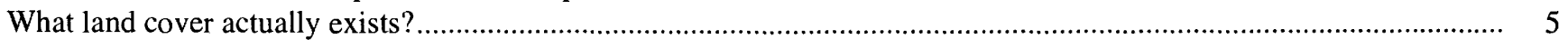

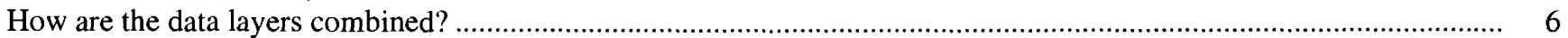

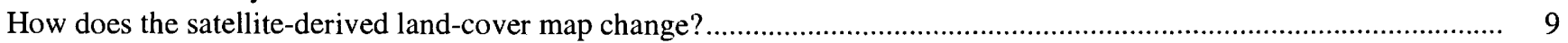

How might these changes influence assessments of water quality? ....................................................................... 10

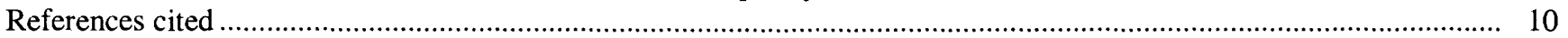

\section{PLATES}

[Plates are in pocket]

1-3. Maps showing:

1. Satellite-derived land-cover classification of the Fox/Wolf River basin

2. Ancillary data that were combined with the classified satellite cover over the Fox/Wolf River basin

3. Land-use/land-cover classification resulting from combining satellite data with ancillary data layers over the Fox/Wolf River basin

\section{FIGURES}

1-2. Maps showing location of:

1. National Water-Quality Assessment Program Study Units

2. The Fox/Wolf River basin in the Western Lake Michigan Drainages Study Unit

3. Diagram showing process of combining satellite data with ancillary data layers to produce a refined land-use/

land-cover map

\section{TABLES}

1. Decision rules applied to satellite-derived land-cover map and ancillary data layers to produce a refined land-use/land-cover map.

2. Comparison of percent land use/land cover between original satellite-derived land-cover and refined land-use/ land-cover maps 


\section{CONVERSION FACTORS}

\begin{tabular}{rll}
\hline Multiply & By & To Obtain \\
\hline & & \\
meter $(\mathrm{m})$ & 3.281 & feet \\
square kilometer $\left(\mathrm{km}^{2}\right)$ & 0.3861 & square mile \\
hectare $(\mathrm{h})$ & 2.471 & acre \\
\hline
\end{tabular}

\section{ACKNOWLEDGMENTS}

\section{Technical Reviewers}

Charles A. Peters, Supervisory Hydrologist, U.S. Geological Survey, Middleton, Wis.

Gail P. Thelin, Geographer, U.S. Geological Survey, Sacramento, Calif.

Kerie J. Hitt, Hydrologist, U.S. Geological Survey, Reston, Va.

\section{Editorial and Graphics}

C. Michael Eberle, Technical Publications Editor, U.S. Geological Survey, Columbus, Ohio

Betty B. Palcsak, Technical Publications Editor, U.S. Geological Survey, Columbus, Ohio

Michelle M. Greenwood, Cartographer, U.S. Geological Survey, Middleton, Wis.

Phillip J. Redman, Geographer, U.S. Geological Survey, Madison, Wis.

Aaron T. Konkol, Cartographic Aid, U.S. Geological Survey, Middleton, Wis.

Susan Z. Jones, Editorial Assistant, U.S. Geological Survey, Middleton, Wis.

\section{Approving Officials}

Daniel P. Bauer, Supervisory Hydrologist, U.S. Geological Survey, Middleton, Wis.

Chester Zenone, Reports Improvement Advisor, U.S. Geological Survey, Reston, Va. 


\title{
Combining Satellite Data with Ancillary Data to Produce a Refined Land-Use/Land-Cover Map
}

\author{
By Jana S. Stewart
}

\section{Abstract}

As part of the U.S. Geological Survey's National Water-Quality Assessment Program in the Western Lake Michigan Drainages Study Unit, a current map of land use and land cover is needed to gain a better understanding of how land use and land cover may influence water quality. Satellite data from the Landsat Thematic Mapper provides a means to map and measure the type and amount of various land-cover types across the Study Unit and can be easily updated as changes occur in the landscape or in water quality. Translating these land cover categories to land use, however, requires the use of other thematic maps or ancillary data layers, such as wetland inventories, population data, or road networks. This report describes a process of (1) using satellite imagery to produce a land-cover map for the Fox/Wolf River basin, a portion of the Western Lake Michigan Drainages NAWQA

Study Unit and (2) improving the satellite-derived land-cover map by using other thematic maps. The multiple data layers are processed in a geographic information system (GIS), and the combination provides more information than individual sources alone.

\section{INTRODUCTION}

In 1991, the U.S. Geological Survey (USGS) began water-quality studies in the Western Lake Michigan Drainages (WMIC) Study Unit of the National WaterQuality Assessment (NAWQA) Program (fig. 1). The WMIC study unit is a $51,541-\mathrm{km}^{2}\left(19,900-\mathrm{mi}^{2}\right)$ area in eastern Wisconsin and the Upper Peninsula of Michigan.

The Fox/Wolf River Basin (fig. 2) is the largest $\left(16,400 \mathrm{~km}^{2} ; 6,332 \mathrm{mi}^{2}\right)$ of 10 major river basins that make up the WMIC Study Unit. More than 50 percent of the basin is characterized by agricultural land use (plates 1 and 3). Most of this agricultural land is in the southern half of the basin and is devoted mostly to crops that support the dairy industry, with corn and hay being the dominant crops. Other important crops include oats, barley, wheat, soybeans, potatoes, snapbeans, and peas. The northern part of the Fox/Wolf River Basin is heavily forested. Here, the upper reaches of the wild and scenic Wolf River flow through State Fishery areas and the Menominee Indian Reservation (Menominee County), whose forests are clearly visible on satellite imagery (plate 1 and fig. 2). Historically, the Wolf River was used as a major logging waterway; today, the stream and surrounding lands are used for recreation, such as fishing, hunting, and canoeing. Extensive areas of wetlands along the lower reaches of the Wolf and the upper reaches of the Fox River include several State wildlife areas that provide excellent habitat for waterfowl. Whereas land use varies north to south from forested to agricultural, surficial deposits vary east to west from clay to sand. This east-west gradation, a result of past glaciation, has led to intensive agricultural cropping on the clay surficial deposits and less intensive, more mixed agricultural/forested land use over the sand and gravel surficial deposits. Although less than 3 percent of the basin is urbanized, more than 250,000 people -about 6 percent of Wisconsin's population-are concentrated in urban areas along the lower Fox River. Some of the greatest changes in land use/land cover in the WMIC Study Unit include the expansion of urban areas around the lower Fox River, Lake Winnebago, and the city of Green Bay since the 1980's. Another important component of the lower Fox River Basin is the pulp and paper industry, and the basin has one of the highest concentrations of pulpmills and papermills in the world.

Changes in land use and land cover, such as increases or decreases in crop acreage or expansion of urban areas, can be identified by reviewing state and county crop reports and the U.S. Bureau of the Census population data, respectively. Although these information sources are valuable, they do not provide informa- 


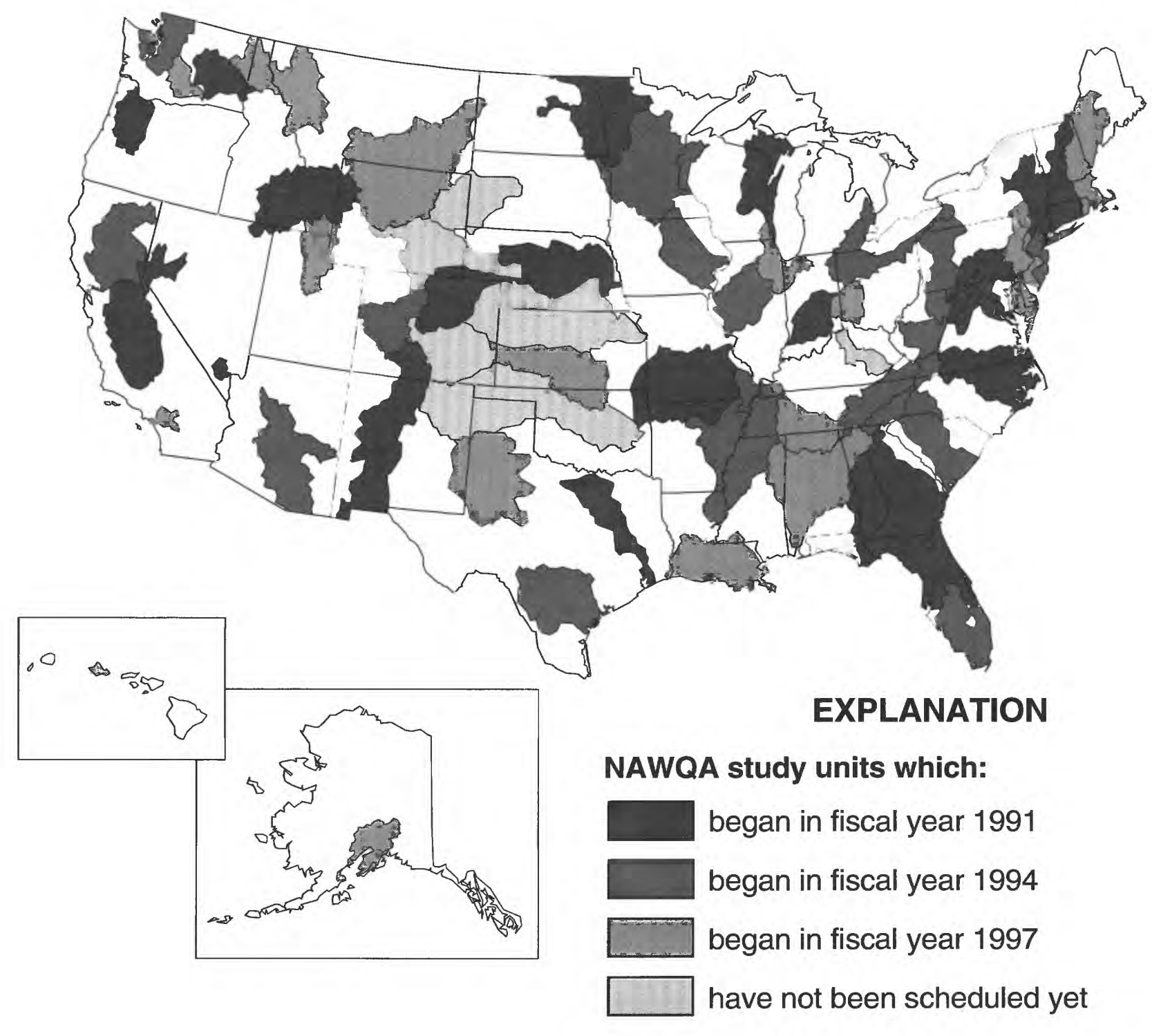

\section{WHAT IS NAWQA?}

The U.S. Geological Survey (USGS) began the National Water-Quality Assessment Program in 1991 for the purpose of (1) describing current water-quality conditions for a large part of the Nation's freshwater streams, rivers, and aquifers, (2) describing trends in water quality over time, and (3) improving our understanding of the primary natural and human factors that affect water-quality conditions. This information will be useful to State and other Federal agencies for planning future management actions and examining their likely consequences (Leahy and Wilber, 1991). Fifty-nine major river basins and aquifers across the country have been identified as NAWQA study units, 53 of these studies were in progress as of March, 1998.

Figure 1. Location of National Water-Quality Assessment Program Study Units. 


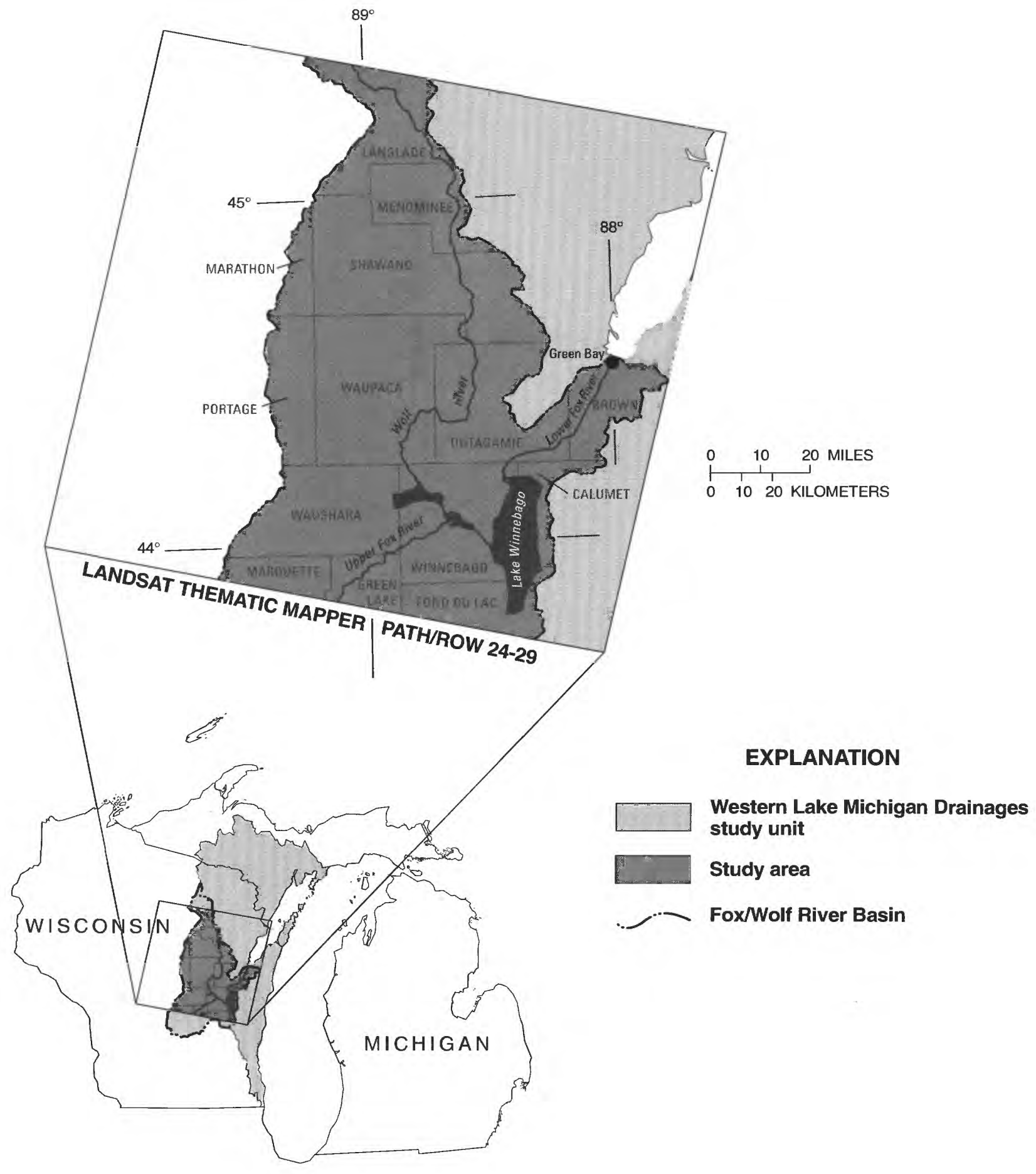

Figure 2. Location of the FoxWolf River Basin in the Western Lake Michigan Drainages Study Unit. 
tion on the areal distribution of land cover. Earthorbiting satellites can provide views or digital images from space that can be used to map and measure the type and amount of various land-cover types across the basin. The Landsat 5 Thematic Mapper (TM) satellite with on-board sensor orbits the earth every 16 days, providing repetitive coverage for the same location, which allows us to view changes that occur in land cover over time.

Although the satellite data are an excellent resource, they too have limitations. But by combining the raw satellite image with other detailed ancillary data, such as crop reports, census data, wetland inventories, hydrography and road networks, we can create a composite data source whose information far exceeds that provided by satellite data alone.

This report describes a process of: (1) using satellite imagery to produce a land-cover map for the Fox/ Wolf River Basin and (2) improving the satellitederived land-cover map by using other thematic maps. The multiple data layers are processed in a geographic information system (GIS), and the combination provides more information than individual data sources alone.

\section{WHY DO WE NEED LAND COVER DATA?}

The land use and land cover near lakes, streams, and aquifers can play an important role in determining the quality of surface water and ground water. In Wisconsin, fields planted with row crops tend to receive increased concentrations and more frequent applications of nutrients and pesticides than land covered with forage crops or pasture. In many places, forested areas protect streamwater quality and habitat by providing a riparian zone. Wetlands can provide a means of filtering some contaminants, by retaining them or by changing them to a less toxic form before they reach surface water or ground water. In areas dominated by urban land use, various contaminants-including pesticides from residential lawn care, trace elements and organic compounds from streets and parking lots, and polychlorinated biphenyls (PCB's) from former industrial activities - may enter streams and/or ground water. Understanding how land use and land cover may influence water quality requires a current map of land cover that can be updated as changes occur in the landscape or in water quality.

\section{HOW CAN LAND COVER BE IDENTIFIED USING SATELLITE IMAGERY?}

In the WMIC NAWQA Study Unit, current land cover needs to be mapped for an area of almost 51,541 $\mathrm{km}^{2}\left(19,900 \mathrm{mi}^{2}\right)$. The only practical and manageable means of identifying land cover that can be easily updated for such an extensive area is satellite imagery. The Landsat TM satellite collects information about the Earth's surface for every 30 - by 30 -m area $(0.09 \mathrm{~h})$, or cell, by recording a reflectance value for seven bands in the electromagnetic spectrum. The combination of these seven values or a subset of these values produces what is considered a unique spectral signature for each cell. A signature can be used to represent many different types of land cover. Depending on the type of land cover, a range of signatures may be required to represent variation within that land-cover category. For example, several signatures may be required to represent all the corn fields in the Fox/Wolf River Basin, depending on the variation in maturity or health of the corn from one field to the next or within any given field: a "full silk" signature, a "lush, leafy green" signature, and a "stunted yellow" signature, to name a few. On the other hand, two types of land cover that are obviously different to the human eye may appear similar to the satellite sensor. For example, cattails (Typha sp.) and corn often look similar on satellite images, and, as a result, their signatures can be easily confused.

Spectral signatures represent land cover but do not indicate land use. What is the difference? Grass growing in a field is considered to be a type of land cover. The land use for that field could be residential, if it is a home lawn; agriculture, if it is a pasture or grain crop; or nonforested wetland, if it is an area covered by herbaceous wetland plants. Land cover can be identified in a satellite image by the use of unique signatures. Land use cannot be identified until an interpreter has determined the purpose or use of the land-cover category. Translating these land cover categories to land use requires the use of other thematic maps or ancillary data layers, such as wetland inventories, population data, or road networks.

\section{HOW CAN OTHER THEMATIC MAPS BE USED TO MAP LAND COVER?}

Many studies have demonstrated the use of thematic maps, or ancillary data layers, to update historical 
land-cover maps or further refine the land-cover data obtained from satellite imagery. The U.S. Bureau of the Census population data have been used to identify areas of new residential development (Hitt, 1994) on historical land-use and land-cover (LUDA) maps (Anderson and others, 1976). These census-derived data also could be used to refine land-cover maps derived from satellite imagery. Where areas of new residential development overlap satellite-derived land-cover classes, such as grassland or deciduous forest, the satellite-derived classes can be renamed to residential land use.

Nagel (1995) overlaid wetland inventory maps with satellite imagery to define the boundaries between uplands and lowlands. These techniques helped eliminate confusion between forested wetlands and forested uplands and between nonforested wetlands and nonforested uplands.

Northcutt (1991) used digital maps of roads to refine the transportation land-use category. This ancillary layer is needed because roads are commonly too narrow to produce clearly defined signatures on satellite imagery. As many as nine contiguous cells $(0.81 \mathrm{~h})$ are often required to produce a distinct signature. The signatures along roads and highways are frequently dominated by the grasses that grow in the transportation right-of-way.

Ecoregion maps have been used to subdivide satellite imagery into homogenous areas based on soils, physiography, vegetation, and climate (Stewart, 1994). In the Fox/Wolf River Basin, six ecoregion subsections define the variation in soils and physiography from east to west and in vegetation and climate from north to south (Albert, 1995). The ecoregion approach eliminates some of the signature confusion between landcover categories (Stewart, 1994) by dividing the satellite image into units that have less signature variation across the image.

Individually, any one of these data layers would have limited use in producing a land-cover map. Combining thematic maps with the satellite image, however provides a means to refine the satellite-derived landcover classes and to identify where changes may have occurred on an existing land-cover map.

\section{WHAT LAND COVER ACTUALLY EXISTS?}

Identifying land cover using satellite imagery requires the image analyst to have a detailed knowledge of the area of interest before proceeding. Information about the actual land cover corresponding to the various parts of the satellite image is commonly termed ground truth. Ground truth helps the analyst to (1) associate signatures with a known type of land cover and (2) check how accurately different types of land cover have been identified in a processed satellite image. For land cover that changes within one season or from one year to the next, ground-truth data must be collected at a time as close as possible to the date of satellite-image acquisition. This is particularly true for cropland because multiple crops may be grown on the same field within one growing season or because different crops may be rotated through the same field from one year to the next. For land-cover categories that are less likely to change, such as forested or urban areas, ground-truth data may be acquired over a wider range of dates.

Ground-truth data may be collected by physically going to a selected location and recording the current land cover (windshield surveys), by interpreting aerial photography that coincides with the date or appropriate range of dates of satellite-image acquisition, or by using other existing sources of ancillary data. Interpreted aerial photography from the USGS National Aerial Photography Program (NAPP) is an excellent source of ground truth and can be used as a base map for compiling ground-truth data. For agricultural crops, detailed cropping information can be obtained from the U.S. Department of Agriculture (USDA) Farm Service Agency (FSA) photologs and crop reports (plate 1). Ground-truth data for forested areas often can be acquired from State and National Forest maps or data bases; for wetlands, from State or National wetland inventories; and for urban areas, from counties, regional planning commissions, or individual city planning offices. Ground-truth data for the Fox/Wolf River Basin were collected during field visits and from FSA photologs and crop reports.

With sufficient ground truth, the analyst can either "train" the computer to associate certain signatures with certain types of land cover (supervised classification) or allow the computer to group signatures that have similar reflectance values (unsupervised classification); in the latter case, the analyst follows up by using ground truth to interpret and label the groups with a land-cover category. Following classification of the satellite data, a separate set of ground-truth information is used to determine how accurately different types of land cover were identified. Many ground-truth sample points are required to determine the accuracy of mapping each 
land-cover category. If an insufficient number of ground-truth points are available for labeling and verification of specific land-cover categories, the analyst may have to aggregate specific land-cover categories into more generalized categories (plate 1), as was done in the Fox/Wolf River Basin study. For example, the category "row crops" includes corn, soybeans, potatoes, snapbeans, and peas; the category "forages and small grains" includes alfalfa, red clover, wheat, barley, and oats; and the category "grasslands" includes pasturelands and unfarmed grasslands.

\section{HOW ARE THE DATA LAYERS COMBINED?}

The utility of Landsat TM imagery can be extended by using it in combination with other thematic maps. Various techniques were used to combine the satellite imagery with other ancillary layers and produce a land cover map for the part of the Fox/Wolf River Basin that overlaps the Landsat TM scene (Path/Row 2429; acquired June 24, 1990). Ancillary data sources used to refine the classification of the satellite imagery included urban boundaries derived from the 1990 U.S. Bureau of the Census TIGER data (U.S. Bureau of the Census, 1990), regional ecoregion boundaries (Albert, 1995), USGS Land Use/Land Cover (LUDA) data (Anderson and others, 1976), U.S. Environmental Protection Agency (USEPA) River Reach File, Version 3.0 (RF3) (U.S. Environmental Protection Agency, 1995) and 1:100,000 scale Class 1 and Class 2 highways from the USGS Digital Line Graphs (DLG's) (U.S. Geological Survey, 1989).

These layers were used in two ways. Before the satellite imagery was processed, urban boundaries derived from the TIGER data and the regional ecoregion boundaries were used to divide the satellite image into units that were spectrally homogenous (had similar spectral reflectance patterns). This process helped to eliminate some of the confusion between signatures, and resulted in one urban stratum and six ecoregion strata. After the satellite imagery was classified, the ancillary data including the USGS Land Use/Land Cover (LUDA) data, USEPA River Reach File (RF3) and 1:100,000scale road data were used to help label forested and nonforested wetlands, urban land use, streams, and roads (fig. 3). These ancillary data sources were used to refine the identification of land use and land cover.
The first step in the process was to define the urban boundaries on the raw satellite image (A in fig. 3) using a variety of information, including spectral reflectance patterns on the satellite image, urban boundaries from the TIGER data, and onscreen digitizing. These outlines were then used as a template to remove the urban part of the satellite image (B in fig. 3 ) in order to reduce the confusion between rural and urban signatures depicting forests and grasslands. The regional ecoregion map (Albert, 1995) was then used to divide the remaining part of the image into spectrally homogeneous units based on a combination of soils, vegetation, climate, and physiography ( $\mathrm{C}$ in fig. 3 ). This helped reduce signature confusion resulting from differences in surficial deposits (clay versus sand), climate (north versus south), and physiography (glacial lake plain versus moraines and outwash plains).

Next, land cover in the nonurban ecoregion units ( $C$ in fig. 3 ) was categorized by means of supervised classification. For instance, a range of signatures from the satellite image that accounts for the variation that exists in corn fields is used as input. The computer program mathematically processes these signatures and finds the cells in the satellite image that have similar signatures. These cells are then labeled as corn. At times there will be confusion between categories, such as "corn" cells that were accidentally labeled as cattails, or "cattail" cells that were accidentally labeled as corn. This confusion can be minimized, but not eliminated, by providing the computer with correctly identified signatures at the outset (based on ground truth) and by dividing the satellite image into spectrally homogenous units before categorization. The following land-cover categories were identified in the Fox/Wolf River Basin using these methods: row crops, forages and small grains, grasslands, deciduous forest, coniferous forest, mixed forest, and water (plate 1). The land-cover maps were checked for accuracy and the ecoregion and urban units were recombined (plate 1, D in fig. 3).

The resulting land-cover map for the Fox/Wolf River Basin was further refined by using decision rules (table 1) in a GIS to incorporate categories that were difficult to identify using satellite data, including wetland, urban, hydrography, and road-network data. This was accomplished by supplying the computer program with various maps, including the satellite-derived land-cover map, the LUDA data, the new residential land-use data (Hitt, 1994), the RF3 streams and the 1:100,000 DLG roads, along with a list of decision rules, as input. The 


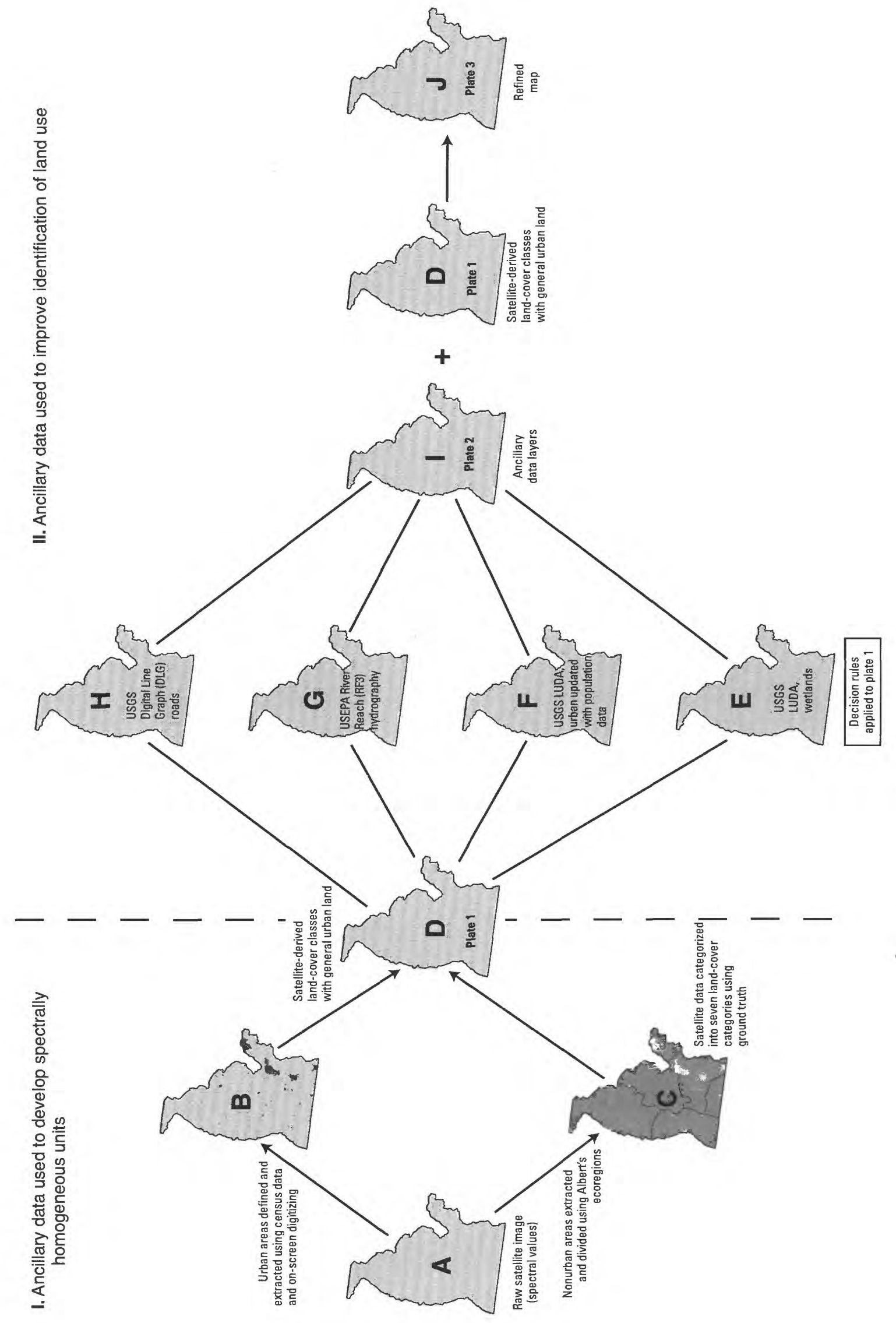

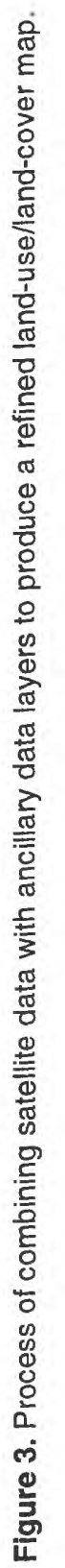




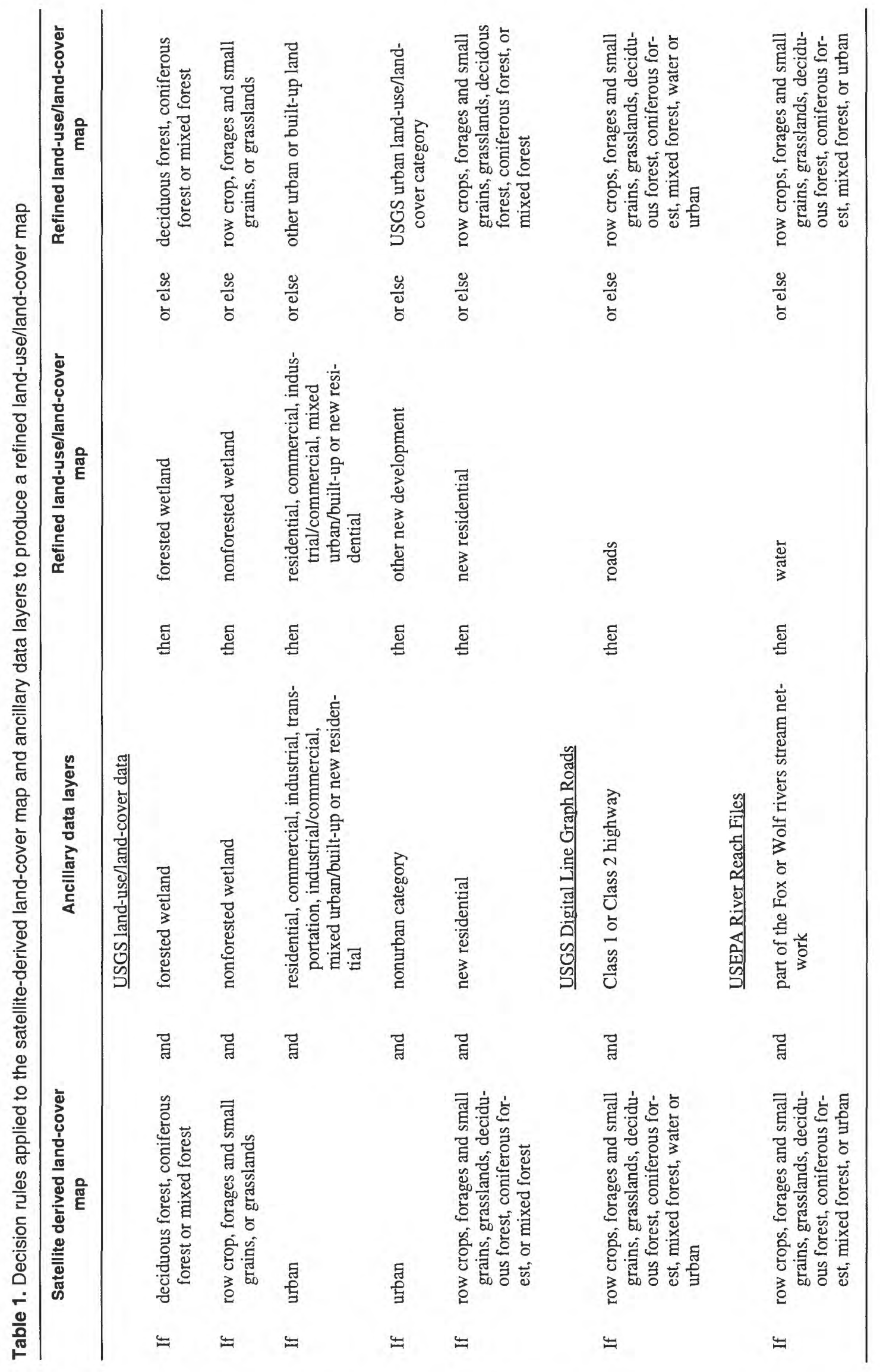


USGS LUDA data were used to refine the wetland category ( $E$ in fig. 3 ) and many urban categories ( $F$ in fig. 3). (Although the LUDA data are somewhat outdated and coarse scaled $(1: 250,000)$, they were the most detailed wetland and urban data available for the WMIC NAWQA at the time of this study. When the Wisconsin Wetland Inventory (1:24,000) (Wisconsin Department of Natural Resources, 1992 (a); Wisconsin Department of Natural Resources, 1992 (b)) becomes available for the study area, these data will be incorporated into the categorized satellite image.) The new residential landuse layer (Hitt, 1994) was a refinement of the LUDA data using the U.S. Bureau of the Census 1990 population density at the block group level. This layer was overlaid with the satellite imagery and LUDA data (F in fig. 3) to incorporate changes that were not detected or reflected by either the satellite imagery or the LUDA data, respectively. The RF3 stream data were used to define stream networks for the Fox and Wolf Rivers where a vegetative canopy obscured the river on the satellite imagery ( $\mathrm{G}$ in fig. 3). The 1:100,000 DLG roads ( $\mathrm{H}$ in fig. 3 ) were used to define roads because of the limitations of defining these using satellite imagery alone. The decision rules were implemented with the use of a computer program that used the specified maps as input. The resulting refined land-cover/land-use map is shown in plate 3 . Changes to the original satellitederived land-cover map (plate 1) are depicted in plate 2 (E, F, G, H in fig 3). In general, the techniques provide a means to label additional land-use/land-cover categories that would not be possible to identify using satellite data alone.

\section{HOW DOES THE SATELLITE-DERIVED LAND-COVER MAP CHANGE?}

The greatest changes made in the general cover categories from the original satellite-derived map (plate 1) to the refined land-use/land-cover map (plate 3) were reduction in the percentage agricultural and forested land and an increase in the percentage of wetland (table 2 , plate 1, plate 2, plate 3). Smaller changes were made in the water and urban land categories. The changes were a result of adding and refining classes on the basis

Table 2. Comparison of percent land use/land cover between original satellite-derived land-cover and refined land-use/land-cover maps

\begin{tabular}{|c|c|c|c|c|c|}
\hline $\begin{array}{l}\text { General land use/ } \\
\text { land cover }\end{array}$ & Original map & Refined map & Detailed land use/land cover & Original map & Refined map \\
\hline \multirow[t]{10}{*}{ Urban } & 2.8 & 3.6 & Urban & 2.8 & -- \\
\hline & & & New residential & -- & 0.51 \\
\hline & & & Residential & -- & 1.5 \\
\hline & & & Commercial & -- & .53 \\
\hline & & & Industrial & -- & .23 \\
\hline & & & Transportation & -- & .18 \\
\hline & & & Industrial/commercial & -- & .01 \\
\hline & & & Mixed urban/built-up & -- & .05 \\
\hline & & & Other urban & -- & .27 \\
\hline & & & Other new development & -- & .41 \\
\hline \multirow[t]{3}{*}{ Agriculture } & 59 & 51 & Row crops & 23 & 20 \\
\hline & & & Forage crops & 20 & 18 \\
\hline & & & Grasslands & 16 & 14 \\
\hline \multirow[t]{3}{*}{ Forest } & 31 & 23 & Deciduous forest & 17 & 14 \\
\hline & & & Mixed forest & 5.9 & 4.3 \\
\hline & & & Coniferous forest & 7.9 & 4.3 \\
\hline \multirow[t]{2}{*}{ Wetland } & -- & 12 & Forested wetlands & -- & 8.2 \\
\hline & & & Nonforested wetlands & -- & 3.9 \\
\hline Water & 7.4 & 7.2 & Water & 7.4 & 7.2 \\
\hline Roads & -- & 3.3 & Roads & -- & 3.3 \\
\hline
\end{tabular}


of the ancillary data. The increase in wetland can be attributed to nonforested wetlands previously being labeled as agriculture and forested wetlands being labeled as forest in the satellite-derived map. No attempt had been made to label wetlands in the satellite-derived map because land use cannot be identified directly from satellite data.The RF3 stream network for the Wolf and Fox Rivers was added to define the stream network where it was obscured by a vegetative canopy. This addition did not dramatically change the water land-cover category. No attempt was made to categorize roads in the satellite-derived map because commonly an image does not contain enough "road" cells to produce a distinct signature. The addition of the road category resulted in a slight reduction in the agriculture category, because the grassy transportation rights-of-way in the satellitederived map were often categorized as agriculture. A reduction in the water category resulted from reclassification because some areas of water were actually wetlands and others were crossed by roads. The increase in the urban land use can be attributed, in part, to the new residential land use (Hitt, 1994) category that was derived from the population data.

Although these changes are not large in terms of percentages, the changes appear more important when viewed in a spatial context (plate 1, plate 2, plate 3 ). Changes related to agriculture, forest, and wetlands were most common in the upper part of the Fox and in the Wolf River Basin, whereas changes to urban area were most common in the lower Fox River Basin. The largest blocks of change were in the central part of the Wolf River Basin, where extensive areas of wetlands increased and the surrounding agricultural areas decreased in size. These same areas were classified as row crops, forages and small grains, grasslands, and forests in the original satellite image. Changes in the extent of urban areas, particularly in the lower Fox River Basin, can mostly be attributed to new residential development and other new development (commercial/industrial/residential). The remaining changes in urban areas were in the existing urban areas where the general urban category was further subdivided using the LUDA urban land-use categories.

\section{HOW MIGHT THESE CHANGES INFLUENCE ASSESSMENTS OF WATER QUALITY?}

In urban areas, the more detailed urban land-use categories (plate 2) derived from ancillary data will better reflect the actual type of land use, whether industrial, residential, or other. These categories can be represented not only spatially (on a map) but also in terms of percentage distribution (in a table) so that effects on water quality can be related to the specific type of urban land use rather than attributed to all types of urban land use. Because the refined map indicates more wetlands and less agriculture than the original satellite-derived landcover map, the potential effects of agriculture on water quality may be reduced. This is not because the map has changed; rather, less land is actually in agriculture than the original map portrayed. Because of decreased agricultural acreage, the amount of nutrients and pesticides entering surface and ground water may also decrease. The addition of the wetland categories not only will result in lower estimates of agricultural inputs but also will provide increased riparian zones to buffer the streams. These buffers can alter the amount, concentration, and form of contaminants that enter surface and ground water, thereby changing the original estimated effects on water quality.

In general, the refined land-use/land-cover map will provide a more accurate and detailed picture of the land use and land cover that influences lakes, streams, and aquifers in the Fox/Wolf Basin. The differences between the original and refined land-cover map (plate 1, plate 2, plate 3) also demonstrate the importance of using ancillary GIS data layers to refine the satellite-derived landcover data. Which thematic maps are used may differ depending on the availability of data and the question at hand. As data layers become available or change, updates can always be made to an existing land-cover map. The techniques for applying these refinements also may vary and are not limited to the techniques described here (Lillesand and Chipman, 1998).

\section{REFERENCES CITED}

Albert, D.A., 1995, Regional landscape ecosystems of Michigan, Minnesota, and Wisconsin, A working map and classification: U.S. Department of Agriculture, Forest Service, North Central Forest Experiment Station General Technical Report NC-178, $250 \mathrm{p}$.

Anderson, J.R., Hardy, E.E., Roach, J.T., and Witmer, R.E., 1976, A land use and land cover classification system for use with remote sensor data: U.S. Geological Survey Professional Paper 964, 28 p.

Hitt, K.J., 1994, Refining 1970's land-use data with 1990 population data to indicate new residential development: U.S. Geological Survey Water-Resources Investigations Report 94-4250, 15 p. 
Leahy, P.P., and Wilber, W.G., 1991, National Water-Quality Assessment Program: U.S. Geological Survey OpenFile Report 91-54, 2 p.

Lillesand, T. and Chipman, J., 1998, Upper Midwest GAP Analysis Program Image Processing Protocol: U.S. Geological Survey, Environmental Management Technical Center Report 98-G001, 25 p.

Nagel, D.E., 1995, Use of preclassification image masking to improve the accuracy of wetland mapping undertaken in support of statewide land cover classification: University of Wisconsin-Madison, Master's thesis, $89 \mathrm{p}$.

Northcutt, Patricia, 1991, The incorporation of ancillary data in the classification of remotely-sensed data: University of Wisconsin-Madison, Master's thesis, $125 \mathrm{p}$.

Stewart, J.S., 1994, Assessment of alternative methods for stratifying Landsat TM data to improve land cover classification accuracy across areas with physiographic vari- ation: University of Wisconsin-Madison, Master's thesis, $159 \mathrm{p}$.

U.S. Bureau of the Census, 1990, TIGER/Line precensus files, 1990: Technical documentation and TIGER /Line files, technical notes, $40 \mathrm{p}$.

U.S. Environmental Protection Agency, 1995, EPA River Reach File Version 3.0 assessment \& revision specification, section 4.3.5, RF3-final database design: $41 \mathrm{p}$.

U.S. Geological Survey, 1989, Digital line graphs from 1:100,000-scale maps-data users guide 2: Reston, Virginia, U.S. Geological Survey, 88 p.

Wisconsin Department of Natural Resources, 1992 (a), A user's guide to the Wisconsin Wetland Inventory: PUBL.-WZ022-92, 4 p.

Wisconsin Department of Natural Resources, 1992 (b), Wisconsin Wetland Inventory classification guide: PUBL.WZ023-92, 4 p. 